\title{
Uji Kelayakan Penuntun Praktikum Genetika Berbasis Keterampilan Proses Sains Berdasarkan Ahli Materi dan Ahli Desain
}

\author{
Ivan Lauren", Fauziyah Harahap, Tumiur Gultom \\ Pendidikan Biologi, Pascasarjana Universitas Negeri Medan, Medan *E-mail: ivanlauren17@yahoo.co.id
}

\begin{abstract}
This research was aimed to develop a Genetics Practical Guidance book Based on Science Process Skills which feasible empirically according to content and design expert. This Genetics Practical Guidance book was developed integrated to 11 components of science process skills in each practicum activity. This science process skills allowed students to explore the information in the form of facts and concepts of science. This study was conducted from April 2016 to August 2016. This research and development used Borg and Gall model. However this study was limited to validation from content expert and design expert. Validation to content experts was carried out to assess the feasibility of the contents, feasibility of the presentation, and the feasibility of science process skills components on the product. Validation of design experts carried out to assess the feasibility of the design of cover, cover typography, content design and content illustration on practical guidance book. Data validation was analyzed descriptively qualitative.The result shown that according to conten experts the product has average percentage of $88.2 \%$ with very good criteria, where as validation from design expert shown the average percentage of $88.3 \%$ with very good criteria. As the conclusion Genetics Practical Guidance book based on Science Process Skills is feasible empirically based on content and design expert to be continue to the next steps.
\end{abstract}

Keywords : Practical Guidance, Genetics, Science Process Skill, Content Expert, Design Expert

Abstrak: Penelitian ini bertujuan untuk mengembangkan Penuntun Praktikum Genetika Berbasis Keterampilan Proses Sains (KPS) yang layak secara empiris menurut ahli materi dan ahli desain. Penuntun praktikum genetika yang dikembangkan mengintegrasikan 11 komponen KPS pada setiap kegiatan praktikum. KPS ini akan memudahkan mahasiswa untuk mencari informasi berupa fakta dan konsep sains. Penelitian ini dilaksanakan pada bulan April 2016 hingga Agustus 2016 Penelitian pengembangan ini menggunakan model Borg \& Gall. Penelitian ini hanya dilakukan sampai pada tahap validasi ahli materi dan desain. Validasi tim ahli materi dilakukan untuk menilai kelayakan isi kelayakan penyajian, dan kelayakan komponen KPS pada penuntun praktikum. Validasi ahli desain dilakukan untuk menilai kelayakan desain kulit, tipografi kulit, desain isi dan ilustrasi isi pada penuntun praktikum. Data hasil validasi dianalisis secara deskriptif kualitatif. Hasil validasi oleh tim ahli materi menunjukkan persentase rata-rata $88,2 \%$ dengan kriteria sangat baik, validasi ahli desain menunjukkan persentase rata-rata $88,3 \%$ dengan kriteria sangat baik. Sebagai kesimpulannya penuntun praktikum yang dikembangkan ini layak menurut ahli materi dan ahli desain untuk dilanjutkan pada tahap berikutnya.

Kata Kunci : Penuntun Praktikum, Genetika, KPS, Ahli Materi, Ahli Desain

\section{PENDAHULUAN}

Genetika merupakan salah satu cabang dari ilmu biologi yang mempelajari faktor keturunan dan organisme. Genetika juga dapat dikatakan adalah studi tentang gen dan segala aspeknya. Secara garis besar, cabang- cabang ilmu genetika meliputi; genetika sel, genetika molekuler, genetika perkembangan, kuantitatif dan genetika populasi. Genetika merupakan satu contoh mata kuliah yang harus diikuti dan dipelajari oleh perserta didik dalam menempuh pendidikan tinggi khususnya pada jurusan biologi.

Sumampouw (2011) mengatakan bahwa perkembangan ilmu biologi rata-rata berasal dari sebuah konsep genetika, dengan kata lain genetika adalah ilmu biologi yang melingkupi seluruh ilmu hayati. Genetika bukanlah sekedar mengenai pewarisan sifat melainkan cabang ilmu biologi yang mempelajari materi genetik, struktur, ekspresi dan keberadaannya dalam populasi serta perekayasaannya (Corebima, 2009). 
Afrida

pembelajaran

(2014)

mengatakan

pembelajaran biologi pengaplikasiannya masih kurang menggunakan lingkungan sekitar sebagai sumber belajar peserta didik dan belum mampu menerapkan keterampilan proses sainsnya dalam pembelajaran. Oleh karena sangat luasnya cakupan yang harus dipelajari dalam bidang genetika ini, maka dalam pembelajaran genetika tidak bisa memperoleh wawasan yang lebih jika hanya mengandalkan pola pembelajaran teoritis namun untuk mengimbanginya perlu dilakukan praktikum.

Kegiatan praktikum dilakukan berdasarkan dari sebuah rencana pembelajaran yang telah ditetapkan dan terlebih dirancang agar sikap psikomotrik mahasiswa atau peserta didik lebih meningkat. Peningkatan sikap psikomotorik yang diharapkan seperti kemampuan menggunakan alat, sikap kerja, kemampuan menganalisis masalah, menyusun urutan kegiatan, kemampuan membaca dan mendeskripsikan gambar serta mampu melakukan suatu kegiatan dengan cepat.

Kegiatan praktikum dianggap menjadi kebiasaan, karena peserta didik hanya mengikuti petunjuk rutin, namun tidak menggunakan keterampilan proses (Rahayuningsih dan Dwiyanto, 2005). Berdasarkan asumsi diatas, tidak salah jika mahasiswa biologi juga beranggapan bahwa kegiatan praktikum genetika juga merupakan sebuah kebiasaan yang wajib dilaksanakan pada saat mata kuliah ini muncul, sebab tidak ada perbedaan dengan kegiatan praktikum lainnya yang tidak mengembangkan keterampilan proses sains. Karena keterampilan proses suatu keterampilan yang melibatkan kemampuan kognitif atau intelektual, manual dan sosial berdasarkan hasil dari sebuah pemikiran (Rustaman, 2003).

Keterampilan proses sains merupakan perangkat kemampuan kompleks yang biasa digunakan oleh para ilmuwan dalam melakukan penyelidikan ilmiah pada rangkaian proses pembelajaran. Menurut Dahar (1996) keterampilan proses sains
(KPS) adalah kemampuan peserta didik untuk menerapkan metode ilmiah dalam memahami, mengembangkan dan menemukan ilmu pengetahuan. Adanya KPS pada diri mahasiswa memudahkannya dalam menggali informasi yang lebih bermanfaat berupa fakta-fakta dan konsep, perkembangan sikap, nilai dan keterampilan berpikirnya juga akan berkembang (Wardani, 2008).

Jika dibandingkan kegiatan praktikum yang menggunakan pembelajaran discovery dengan KPS, keduanya memliki kesamaan yaitu meningkatkan kemampuan untuk memecahkan sebuah masalah dari teori kedalam sebuah permasalahan yang lebih nyata (kognitif) dan melatih peserta didik untuk berpikir kritis dan aktif bekerja. Namun terdapat perbedaan dari kedua model pembelajaran tersebut, jika model discovery lebih cocok untuk mengembangan pemahaman peserta didik dan aspek lainnya kurang mendapatkan perhatian. Sedangkan dengan model KPS, pemahaman peserta didik terhadap objek nyata, kemampuan untuk menemukan dan mengembangkan sendiri konsep serta keterampilan dan emosi secara keseluruhan sangat diperhatikan (Dimyati, 2009).

Penuntun praktikum merupakan pedoman peserta didik dalam menguji dan melaksanakan secara nyata sesuatu yang diperoleh berupa konsep dari teori. Penelitian Nikmah, dkk (2015) disebutkan bahwa diktat praktikum adalah buku penunjang kegiatan praktikum yang berisi materi dan serangkaian prosedur kerja yang akan dilakukan dalam praktikum, sehingga keberadaan diktat praktikum ini dapat mempengaruhi keberhasilan pembelajaran di laboratorium karena sebagai acuan peserta didik.

Asy'syakurni (2015) menerangkan bahwa petunjuk praktikum diperlukan pada saat melaksanakan praktikum karena selain mampu membantu pelaksanaan praktikum juga memberikan bantuan berupa informasi bagi peserta didik. Penggunaan petunjuk praktikum dapat membantu membawa peserta didik menemukan pengetahuannya 
serta mampu memahami suatu konsep materi.

Penelitian Zulaiha (2014) yang mengembangkan sebuah penuntun praktikum kimia berbasis keterampilan proses sains diperoleh hasil bahwa dengan penggunaan penuntun praktikum berbasis KPS peserta didik dapat meningkatkan seluruh kemampuan KPS peserta didik. Sehingga dengan penuntun praktikum berbasis KPS memiliki efek potensial terhadap hasil belajar peserta didik.

Berdasarkan angket pra-penelitian penuntun praktikum genetika di Jurusan Biologi yang ada saat ini masih berbasis discovery, tidak adanya penuntun praktikum genetika berbasis KPS, sehingga keterampilan proses sains mahasiswa belum seutuhnya berkembang dengan baik. Dengan dikembangkannya sebuah penuntun praktikum genetika berbasis KPS diharapkan akan memudahkan mahasiswa dalam menggali informasi yang bermanfaat, menemukan fakta-fakta dan konsep (Wardani, 2008).

\section{METODE PENELITIAN}

Penelitian ini merupakan penelitian pengembangan dengan model Borg \& Gall.
Penelitian ini dilaksanakan pada bulan April 2016 hingga Agutustus 2016. Validasi yang dilakukan oleh 3 dosen ahli materi dan 1 dosen ahli desain bertujuan untuk mengetahui kelayakan penuntun praktikum genetika berbasis KPS yang dikembangkan secara teoritis. Instrumen yang digunakan adalah lembar validasi yang meliputi aspek kelayakan isi materi, kelayakan penyajian, komponen KPS dan kelayakan desain. Metode pengumpulan data dalam penelitian ini adalah dengan metode pengumpulan hasil validasi, kemudian data yang didapatkan dianalisis secara deskriptif kualitatif.

\section{HASIL DAN PEMBAHASAN \\ Penilaian Kelayakan Penuntun Praktikum Genetika berbasis KPS oleh Validator Ahli Materi}

Berdasarkan penilaian yang diberikan oleh tim ahli materi terhadap kelayakan isi produk yang dikembangkan memiliki total persentase rata-rata sebesar $85 \%$ dan dinyatakan sangat baik/sangat layak. Hasil validasi dari tim ahli materi terhadap kelayakan isi penuntun praktikum dapat dilihat pada Tabel 4.2.

Tabel 1. Penilaian Komponen Kelayakan Isi Penuntun Praktikum Genetika Berbasis Keterampilan Proses Sains oleh Tim Ahli Materi

\begin{tabular}{|c|c|c|c|c|c|c|c|c|}
\hline \multirow{2}{*}{ Komponen } & \multirow{2}{*}{ Indikator } & \multirow{2}{*}{$\begin{array}{l}\text { Jhh } \\
\text { Item }\end{array}$} & \multicolumn{3}{|c|}{ Validator } & \multirow{2}{*}{$\begin{array}{l}\text { Skor } \\
\text { Total }\end{array}$} & \multirow{2}{*}{$\begin{array}{c}\% \\
\text { Rata- } \\
\text { rata }\end{array}$} & \multirow[b]{2}{*}{ Kriteria } \\
\hline & & & 1 & 2 & 3 & & & \\
\hline \multirow{4}{*}{$\begin{array}{l}\text { Kelayakan } \\
\text { Isi Penuntun } \\
\text { Praktikum }\end{array}$} & Kesesuaian Konsep & 3 & 12 & 14 & 12 & 38 & 84,5 & SB \\
\hline & Kedalaman Konsep & 3 & 13 & 15 & 12 & 40 & 89 & SB \\
\hline & Keakuratan Materi & 10 & 45 & 40 & 40 & 125 & 83,3 & SB \\
\hline & $\begin{array}{l}\text { Materi Pendukung } \\
\text { Perkuliahan }\end{array}$ & 3 & 14 & 13 & 12 & 39 & 86,7 & SB \\
\hline \multicolumn{2}{|c|}{ Skor Total } & 19 & 84 & 82 & 76 & 242 & 85 & $\mathrm{SB}$ \\
\hline
\end{tabular}

Berdasarkan hasil validasi terhadap komponen kelayakan isi penuntun praktikum yang telah direvisi, diperoleh persentase rata-rata untuk indikator kesesuaian konsep 84,5\%, kedalaman konsep $89 \%$, keakuratan materi $83,3 \%$ dan persentase rata-rata untuk materi pendukung perkuliahan sebesar $86,7 \%$, dengan kriteria "Sangat baik" untuk semua indikator. Dari hasil tersebut menunjukkan bahwa pada kelayakan penyajian penuntun praktikum Genetika yang telah dikembangkan dinyatakan layak dan memenuhi syarat untuk dipergunakan dari segi kelayakan isi penuntun praktikum. 
Data tersebut telah disajikan dalam bentuk diagram dan dapat dilihat pada Gambar 1.

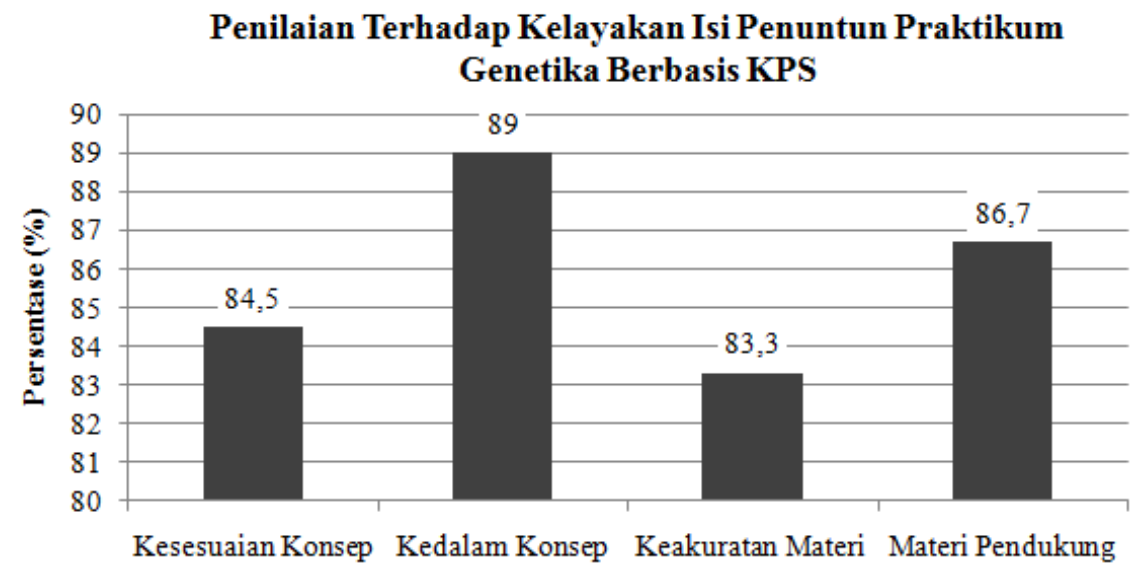

Indikator Komponen Kelayakan Isi Produk

Gambar 1. Penilaian terhadap kelayakan isi penuntun praktikum genetika berbasis KPS oleh ahli materi

Penilaian yang diberikan oleh tim ahli materi terhadap kelayakan penyajian produk yang dikembangkan memiliki total persentase rata-rata sebesar $90,4 \%$ dan dinyatakan sangat baik/sangat layak. Data hasil validasi tim ahli materi terhadap kelayakan penyajian penuntun praktikum dapat dilihat pada Tabel 2.

Tabel 2. Penilaian terhadap kelayakan penyajian penuntun praktikum genetika berbasis KPS oleh ahli materi

\begin{tabular}{|c|c|c|c|c|c|c|c|c|}
\hline \multirow{2}{*}{ Komponen } & \multirow{2}{*}{ Indikator } & \multirow{2}{*}{$\begin{array}{l}\text { Jh } \\
\text { Item }\end{array}$} & \multicolumn{3}{|c|}{ Validator } & \multirow{2}{*}{$\begin{array}{l}\text { Skor } \\
\text { Total }\end{array}$} & \multirow{2}{*}{$\begin{array}{c}\% \text { Rata- } \\
\text { rata }\end{array}$} & \multirow{2}{*}{ Kriteria } \\
\hline & & & 1 & 2 & 3 & & & \\
\hline \multirow{5}{*}{$\begin{array}{l}\text { Kelayakan } \\
\text { Penyajian } \\
\text { Penuntun } \\
\text { Praktikum }\end{array}$} & Teknik Penyajian & 6 & 29 & 27 & 25 & 81 & 90 & SB \\
\hline & Kejelasan Kalimat & 2 & 9 & 10 & 7 & 26 & 86,7 & SB \\
\hline & Kebahasaan & 2 & 10 & 8 & 7 & 25 & 83,3 & SB \\
\hline & $\begin{array}{l}\text { Penyajian dan } \\
\text { pembelajaran }\end{array}$ & 3 & 14 & 14 & 15 & 43 & 95,6 & SB \\
\hline & $\begin{array}{l}\text { Kelengkapan } \\
\text { penyajian }\end{array}$ & 3 & 15 & 15 & 12 & 42 & 93,3 & SB \\
\hline \multicolumn{2}{|c|}{ Skor Total } & 16 & 77 & 74 & 66 & 217 & 90,4 & SB \\
\hline
\end{tabular}

Berdasarkan hasil validasi terhadap komponen kelayakan penyajian Penuntun Praktikum yang telah direvisi, dituliskan bahwa indikator teknik penyajian mempunyai persentase rata-rata $90 \%$, indikator kejalasan kalimat dengan persentase rata-rata $86,7 \%$, indikator kebahasaan dengan persentase rata-rata $83,3 \%$, indikator penyajian dan pembelajaran mempunyai persentase ratarata $95,6 \%$ dan indikator kelengkapan penyajian mempunyai persentase rata-rata 93,3\% dengan kriteria "Sangat baik" untuk semua indikator. Dari hasil tersebut menunjukkan bahwa pada kelayakan penyajian penuntun praktikum Genetika yang telah dikembangkan dinyatakan layak dan memenuhi syarat untuk dipergunakan dari segi kelayakan penyajian. Data tersebut telah disajikan dalam bentuk diagram dan dapat dilihat pada Gambar 2. 
Penilaian Terhadap Kelayakan Penyajian Penuntun Praktikum Genetika Berbasis KPS

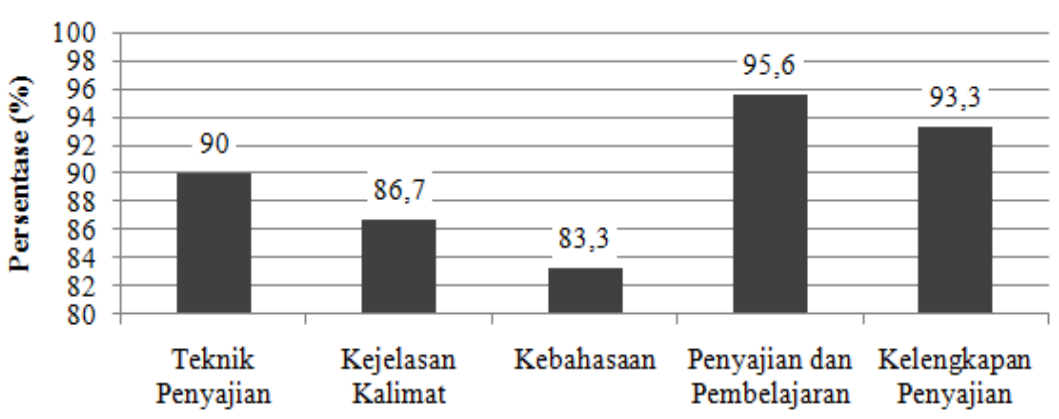

Indikator Komponen Kelayakan Penyajian Produk

Gambar 2. Penilaian terhadap kelayakan penyajian penuntun praktikum genetika berbasis KPS oleh ahli materi

Selain komponen kelayakan isi dan penyajian, komponen keterampilan proses sains menjadi komponen lain yang disoroti pada pengembangan penuntun praktikum ini, seperti yang terlihat pada Tabel 3 .

Tabel 3. Penilaian Komponen Keterampilan Proses Sains pada Penuntun Praktikum Genetika Berbasis Keterampilan Proses Sains oleh Tim Ahli Materi

\begin{tabular}{|c|c|c|c|c|c|c|c|c|}
\hline \multirow{2}{*}{ Komponen } & \multirow{2}{*}{ Indikator } & \multirow{2}{*}{$\begin{array}{l}\text { Jlh } \\
\text { Item }\end{array}$} & \multicolumn{3}{|c|}{ Validator } & \multirow{2}{*}{$\begin{array}{l}\text { Skor } \\
\text { Total }\end{array}$} & \multirow{2}{*}{$\begin{array}{c}\% \text { Rata- } \\
\text { rata }\end{array}$} & \multirow{2}{*}{ Kriteria } \\
\hline & & & 1 & 2 & 3 & & & \\
\hline \multirow{11}{*}{$\begin{array}{l}\text { Kelayakan } \\
\text { Komponen } \\
\text { Keterampilan } \\
\text { Proses Sains }\end{array}$} & Mengamati & 2 & 8 & 8 & 10 & 26 & 86,7 & SB \\
\hline & Mengklasifikasikan & 3 & 12 & 14 & 13 & 39 & 86,7 & SB \\
\hline & Meramalkan & 2 & 9 & 9 & 8 & 26 & 86,7 & SB \\
\hline & $\begin{array}{l}\text { Mengajukan } \\
\text { Pertanyaan }\end{array}$ & 2 & 10 & 9 & 10 & 29 & 96,7 & SB \\
\hline & $\begin{array}{l}\text { Merumuskan } \\
\text { Hipotesis }\end{array}$ & 2 & 8 & 9 & 8 & 25 & 83,3 & SB \\
\hline & $\begin{array}{l}\text { Merencanakan } \\
\text { Percobaan }\end{array}$ & 3 & 15 & 14 & 14 & 43 & 95,6 & SB \\
\hline & $\begin{array}{l}\text { Menggunakan } \\
\text { Alat/Bahan }\end{array}$ & 2 & 9 & 9 & 9 & 27 & 90 & SB \\
\hline & $\begin{array}{l}\text { Menetapkan } \\
\text { Konsep }\end{array}$ & 2 & 9 & 8 & 8 & 25 & 83,3 & SB \\
\hline & Mengukur & 2 & 10 & 9 & 8 & 27 & 90 & SB \\
\hline & Menghitung & 1 & 5 & 5 & 4 & 14 & 93,3 & SB \\
\hline & Berkomunikasi & 4 & 16 & 18 & 20 & 54 & 90 & SB \\
\hline & or Total & 25 & 111 & 112 & 112 & 335 & 89,3 & SB \\
\hline
\end{tabular}

Berdasarkan hasil validasi yang dilakukan terhadap komponen keterampilan proses sains dengan 11 indikator yang dinilai, dituliskan bahwa pada indikator mengamati memiliki persentase rata-rata $86,7 \%$, indikator mengklasifikasikan memiliki persentase rata-rata $86,7 \%$, indikator meramalkan persentase rataratanya $86,7 \%$, indikator mengajukan pertanyaan persentase rata-rata $96,7 \%$, indikator merumuskan hipotesis memiliki persentase rata-rata $83,3 \%$, indikator merencanakan percobaan memiliki persentase rata-rata $95,6 \%$, indikator menggunakan alat/bahan persentase ratarata $90 \%$, indikator menetapkan konsep persentase rata-rata $83,3 \%$, indikator mengukur persentase rata-ratanya $90 \%$, indikator menghitung persentase rata-rata 93,3\%, dan indikator berkomunikasi persentase rata-ratanya sebesar $90 \%$ dengan kriteria untuk keseluruhan indikator yaitu 
"Sangat Baik", maka penuntun praktikum Genetika yang telah dikembangkan berbasis keterampilan proses sains dinyatakan valid namun perlu direvisi sesuai dengan saran perbaikan. Data tersebut telah disajikan dalam bentuk diagram dan dapat dilihat pada Gambar 3.

\section{Penilaian Terhadap Kelayakan Indikator KPS pada Penuntun Praktikum Genetika Berbasis KPS}

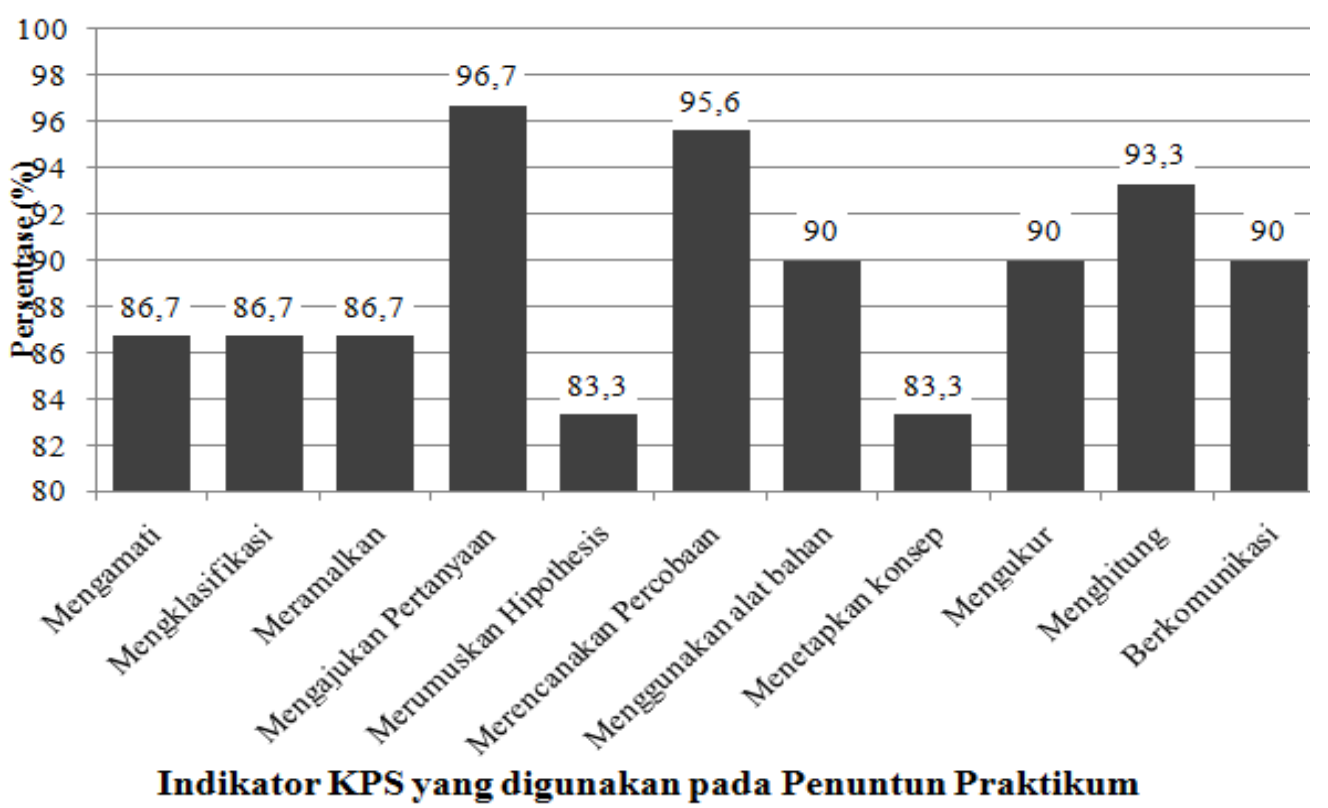

Gambar 3. Diagram penilaian kelayakan Penuuntun Praktikum Genetika berbasis KPS terhadap indikator KPS

\section{Penilaian Kelayakan Penuntun Praktikum Genetika berbasis KPS oleh Validator Ahli Desain}

Berdasarkan penilaian oleh ahli desain terhadap kelayakan penuntun praktikum genetika berbasis KPS yang dikembangkan, diperoleh data sebagai berikut:

Tabel 4. Penilaian Komponen Desain Pada Penuntun Praktikum Genetika Berbasis Keterampilan Proses Sains oleh Ahli Desain

\begin{tabular}{|c|c|c|c|c|c|}
\hline Aspek Penilaian & $\begin{array}{l}\text { Jlh } \\
\text { Item }\end{array}$ & $\begin{array}{l}\text { Validator } \\
\text { desain }\end{array}$ & $\begin{array}{l}\text { Total } \\
\text { skor }\end{array}$ & $\begin{array}{l}\text { \% Rata- } \\
\text { rata }\end{array}$ & Kriteria \\
\hline Desain kulit & 5 & 24 & 24 & 96 & SB \\
\hline Tipografi Kulit & 4 & 19 & 19 & 95 & SB \\
\hline Desain Isi & 11 & 49 & 49 & 89 & SB \\
\hline Ilustrasi Isi & 4 & 14 & 14 & 70 & B \\
\hline $\begin{array}{l}\text { Skor Total Untuk Semua Aspek } \\
\text { Penilaian Desain }\end{array}$ & 24 & 106 & 106 & \multirow[t]{2}{*}{88,3} & \multirow[t]{2}{*}{ SB } \\
\hline \% Semua Aspek Pen & $\operatorname{aian} \mathbf{D}$ & & & & \\
\hline
\end{tabular}

Berdasarkan hasil validasi yang dilakukan oleh ahli desain, disimpulkan bahwa desain penuntun praktikum yang dikembangkan memiliki total persentase rata-rata sebesar 88,3\%, dengan kriteria untuk keseluruhan indikator "Sangat Baik" dan layak untuk digunakan dalam praktikum genetika di laboratorium. Data 
tersebut telah disajikan dalam bentuk diagram dan dapat dilihat pada Gambar 4.

Penilaian pada Desain Penuntun Praktikum Genetika Berbasis KPS

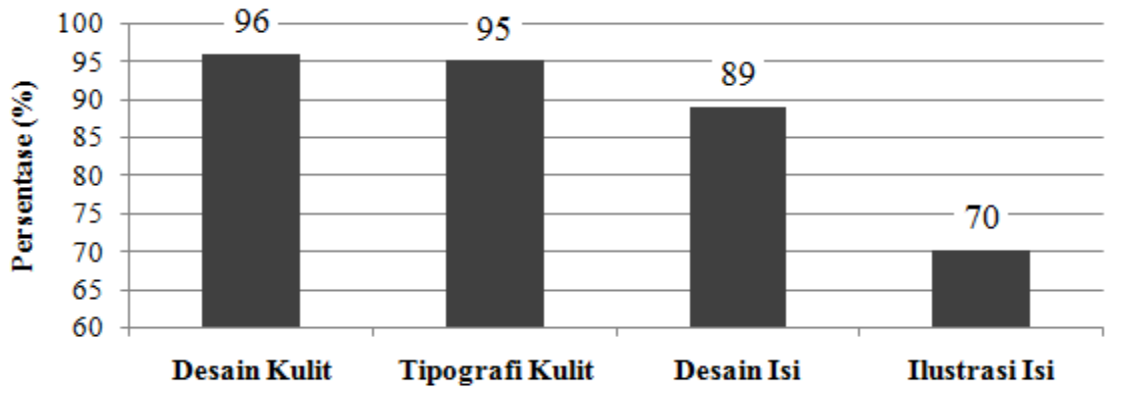

Aspek Penilaian pada Desain Produk

Gambar 4. Diagram penilaian kelayakan Desain Penuntun Praktikum Genetika berbasis KPS oleh Ahli Desain

\section{KESIMPULAN}

Berdasarkan hasil dan pembahasan penelitian pengembangan penuntun praktikum Genetika berbasis keterampilan proses sains ini, maka dapat disimpulkan bahwa Penuntun praktikum genetika berbasis KPS dikategorikan "sangat baik" dan layak digunakan pada praktikum genetika di laboratorium. Dengan persentase rata-rata $88,2 \%$ (sangat baik) oleh ahli materi, dan persentase rata-rata $88,3 \%$ (sangat baik) menurut ahli desain.

\section{DAFTAR PUSTAKA}

Afrida, I.R., M. Amin., dan A. Ghofur., (2014)., Pengembangan Bahan Ajar Matakuliah Genetika Populasi Berbasis Penelitian Keragaman Genetik Kerbau Lokal Tana Toraja dan Lombok. Jurnal Kependikan 13 (4): 337-347.

Asy'syakurni, N.A., A. Widiyatmoko., Parmin., (2015)., Efektivitas Penggunaan Petunjuk Praktikum IPA Berbasis Inkuiri pada Tema Kalor dan Perpindahannya Terhadap Keterampilan Proses Sains Peserta Didik. Unnes Science Education Journal 4 (3) : 952-958.

Corebima, A.D., (2009). Pengalaman Berupaya Menjadi Guru Profesional, Pidato Pengukuhan Guru Besar Dalam Bidang Genetika. Malang. FMIPA Universitas Negeri Malang.

Rahayuningsih, E, dan Dwiyanto, D. (2005). Pembelajaran di Laboratorium. Pusat Pengembangan Pendidikan UGM: Yogyakarta.
Rustaman, A. (2005). Pengembangan Kompetensi (Pengetahuan, Keterampilan, Sikap Dan Nilai) Melalui Kegiatan Praktikum Biologi. Penelitian Jurusan Pendidikan Biologi FPMIPA UPI Bandung.

Sumampouw, H.M., (2011) Keterampilan Metakognitif dan Berpikir Tingkat Tinggi dalam Pembelajaran Genetika (Artikulasi Konsep dan Verifikasi Empiris). Jurnal BIOEDUKASI 2 (4): 23-29.

Trianto., (2010). Model Pembelajaran Terpadu dalam Teori dan Praktek. Jakarta: Prestasi Pustaka.

Wardani, S., (2008). Pengembangan Keterampilan Proses Sains Dalam Pembelajaran Kromatografi Lapis Tipis Melalui Praktikum Skala Mikro. Jurnal Inovasi Pendidikan Kimia (2) 2: 317-322.

Zulaiha., Hartono., dan A.R. Ibrahim. (2014). Pengembangan Buku Penuntun Praktikum Kmia Hidrokarbon berbasis Keterampilan Proses Sains di SMA. J.Pen.Pend. Kimia, 2014 (1) 1: 87-93.

Zeidan, A. H., R. J. Majdi., (2015)., Science Process Skills and Attitudes toward Science among Palestinian Secondary School Students World Journal of Education Vol. 5 (1): 13-24. 